\title{
A CASE OF PRIMARY FALLOPIAN TUBE CARCINOMA DIAGNOSED RADIOLOGICALLY BEFORE OPERATION
}

\author{
June Kuk Choi, MD1', Jun Yong Choi, MD', Sun Yeon Kim, MD', Sun Young Kwon, MD², So Jin Shin, MD', \\ Chi Heum Cho, MD', Soon Do Cha, MD', Sang Hoon Kwon, MD ${ }^{1}$ \\ Departments of ${ }^{1}$ Obstetrics and Gynecology, ${ }^{2}$ Pathology, Keimyung University School of Medicine, Daegu, Korea
}

Primary fallopian tube carcinoma is one of the rarest gynecological malignancies, accounting for $0.18 \%$ to $1.6 \%$ of all malignant neoplasms of the female reproductive tract. Preoperative diagnosis was difficult due to nonspecific symptoms and signs. This case of primary tubal cancer was diagnosed preoperatively on the basis of ultrasonography, computed tomography and magnetic resonance imaging. We have experienced a case of primary fallopian tube carcinoma before operation and so report with brief review of the literature.

Keywords: Primary fallopian tube cancer; Preoperative; Diagnosis

원발성 난관암은 발생 빈도가 낮은 부인암으로, 모든 원발성 여성 생 식계암 중 $0.15 \%-1.8 \%$ 를 차지한다. 난관암은 수술 전 진단이 매우 어 려운 부인과 종양 중의 하나로 알려져 있는데, 이는 첫째로 질병자체의 발생빈도가 낮으며, 둘째로 임상증상이나 증후가 다른 부인과 질환에 서 흔히 볼 수 있는 비특이적 양상을 나타내며, 마지막으로 여러 진단 적 기법이 난관암을 인지하는 데 있어 민감하지 못하기 때문이라고 여 겨진다. 저자들은 질출혈과 부속기 종괴를 주소로 외래 방문한 폐경기 여성에서 영상학적 검사를 통해 수술 전 진단된 원발성 난관암 1 예를 경험하였기에 문헌고찰과 함께 보고하는 바이다.

\section{증 례}

\section{환 자: 남 $\mathrm{O} 0,58$ 세, 주부 \\ 주 소: 8개월간의 비정기적 질출혈}

현병력: 환자는 최근 8개월간 비정기적인 질출혈이 있었으나 별 다른 치료를 하지 않았고, 이후 출혈이 심해져서 개인병원 방문 후 부속기 종양이 의심되어 본원으로 전원되었다.

과거력: 고혈압으로 1 년 전부터 개인 내과병원에서 치료 중이었다.

수술력: 없었다.

가족력: 특이 소견 없었다.

산과력: 2-0-0-2

이학적 소견: 병원 방문 당시 환자의 의식 상태는 명료하였으며 체중 은 $52 \mathrm{~kg}$, 신장은 $161 \mathrm{~cm}$, 혈압은 130/85 mm Hg, 맥박은 76회/분, 체온은 $36.7^{\circ} \mathrm{C}$ 였다. 흉부청진 소견은 정상이었고, 복부촉진상 압통이
나 반발통은 없었다. 배변장애 및 구토는 호소하지 않았다. 골반내진 소견상 자궁은 전굴, 위축되어 있었고 압통은 없었으며 양측 자궁부속 기 부위에서 촉지되는 종괴나 압통은 없었다.

검사 소견: 내원 당시 시행한 혈액검사상 혈색소 $14.5 \mathrm{~g} / \mathrm{dL}$, 적혈 구 용적 $45.1 \%$, 백혈구 $13,200 / \mathrm{mm}^{3}$ (분획 호중구 $93.9 \%$ ), 혈소

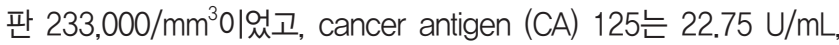
CA19-9는 7.24 U/mL였다. 그 외 일반 혈액검사, 소변검사, 흉부X-선 및 심전도검사는 정상이었다. 질출혈을 호소하여 자궁내막조직검사를 시행하여 병리학적으로 특이 소견은 없었다.

골반초음파검사: 양측 정상난소가 확인되면서 우측 자궁부속기 주위 에 $6.2 \times 3.0 \mathrm{~cm}$, 좌측 자궁부속기 주위에 $5.0 \times 2.5 \mathrm{~cm}$ 크기의 소시지 모양의 낭성 종괴가 보였으며 자궁내막에 $2 \mathrm{~cm}$ 크기의 종괴가 보여 난

Received: 2012.5.24. Revised: 2012.8.10. Accepted: 2012.9.17. Corresponding author: Sang Hoon Kwon, MD Department of Obstetrics and Gynecology, Keimyung University School of Medicine, 56 Dalseong-ro, Jung-gu, Daegu 700-712, Korea

Tel: +82-53-250-7992 Fax: +82-53-250-7599

E-mail: ksh1999@dsmc.or.kr

This is an Open Access article distributed under the terms of the Creative Commons Attribution Non-Commercial License (http://creativecommons.org/licenses/ by-nc/3.0/) which permits unrestricted non-commercial use, distribution, and reproduction in any medium, provided the original work is properly cited.

Copyright $\odot$ 2012. Korean Society of Obstetrics and Gynecology 


\section{KOREAN JOURNAL OF OBSTETRICS \& GYNECOLOGY}

KJOG Vol. 55, No. 11, 2012

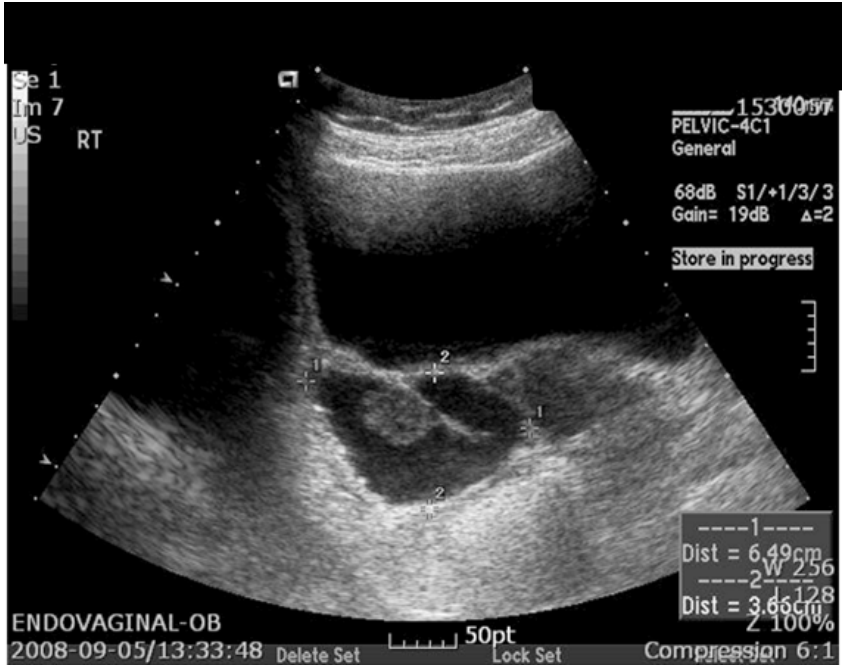

Fig. 1. Ultrasonographic finding of the primary fallopian tube cancer. It shows a bilocular cystic mass with intramural nodule, measuring $65 \times 36 \mathrm{~mm}$.

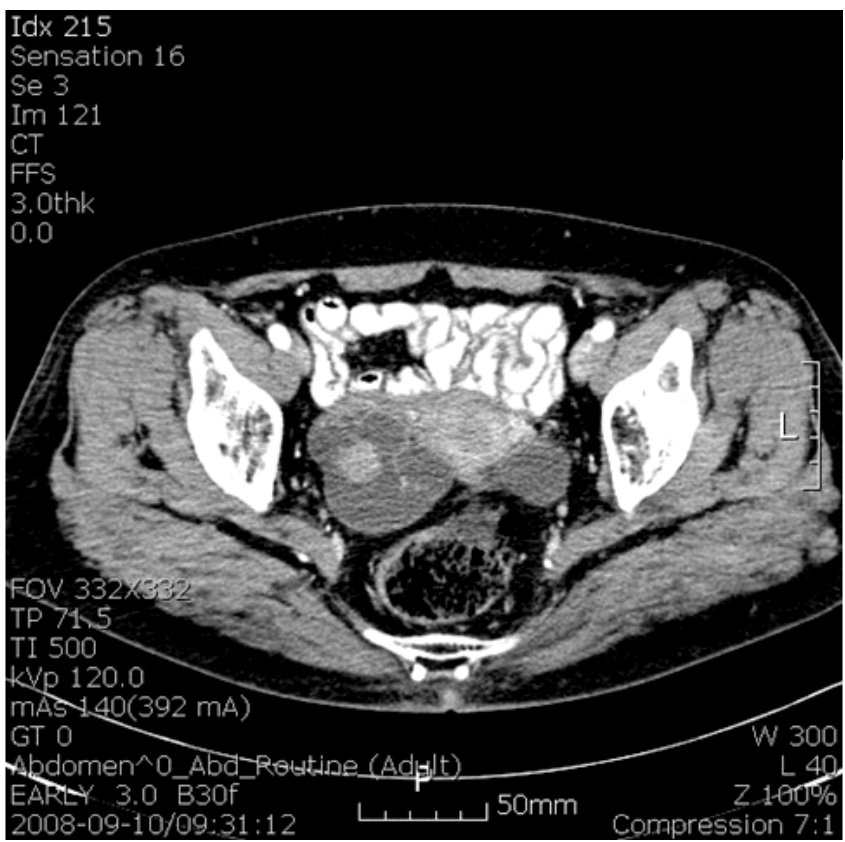

Fig. 2. Pelvic computed tomography finding of the primary tube cancer. Bilateral tubular shaped cystic masses with a nodular enhancing solid mass in the cystic mass of the right one (right, measuring $60 \times 43 \times 55 \mathrm{~mm}$; left, $53 \times 29 \mathrm{~mm}$ ).

관암이나 자궁내막암이 의심되었다(Fig. 1).

복부 전산화단층촬영검사: 자궁의 좌측 기저부에 $2 \mathrm{~cm}$ 크기의 점막하 근종이 의심되는 종괴가 보였다. 양측 부속기 모두에 낭성부분으로 보 이는 종괴가 보였는데, 우측 자궁부속기는 $6.0 \times 4.3 \times 5.5 \mathrm{~cm}$ 크기의 낭성 종괴가 보였고, 좌측 자궁 부속기는 $5.3 \times 2.9 \mathrm{~cm}$ 크기의 난관수 종이 의심되어서, 난관암 혹은 내막암이 의심되었다(Fig. 2).

자기공명영상 소견: 우측 자궁부속기는 $5.6 \times 4.5 \times 4.5 \mathrm{~cm}$ 크기의 낭성

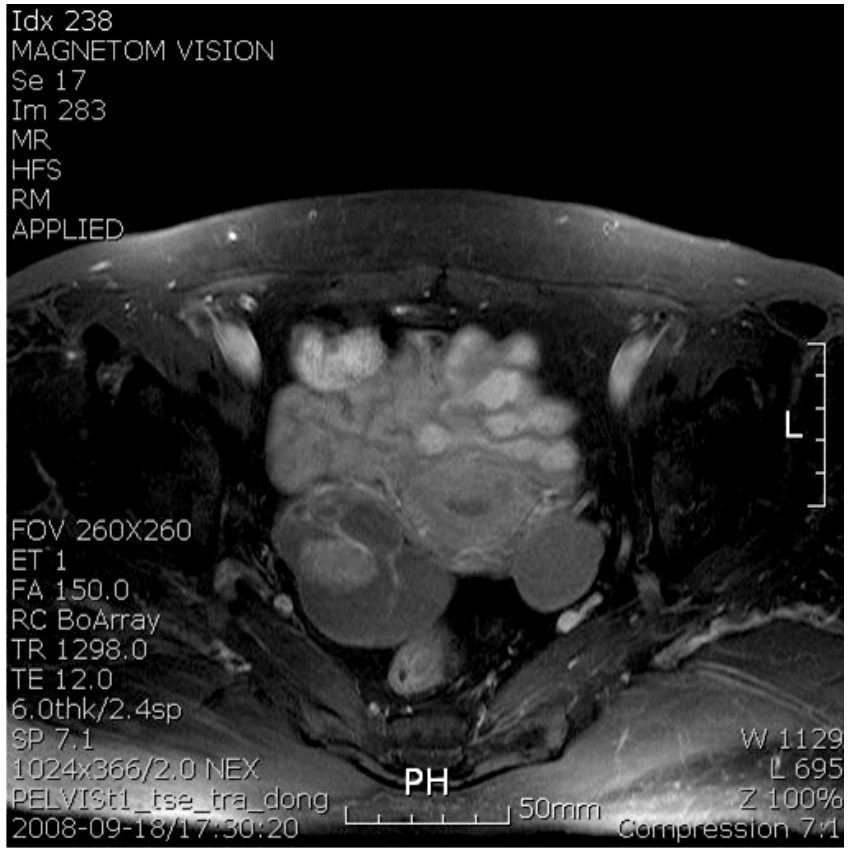

Fig. 3. Pelvic magnetic resonance imaging finding of the primary tubal cancer. Bilateral tubular shaped cystic masses with high S1 on T2W1 with an enhancing solid mural nodule in the Rt. cystic mass, measuring $56 \times 45 \times 45 \mathrm{~mm}$ on right and $50 \times 24 \times 50 \mathrm{~mm}$ on left.

종괴가 확인되었다. 그 외는 복부 전산화단층촬영의 소견과 동일하였 다(Fig. 3).

수술적 소견: 전신마취하에 중간선절개로 개복술을 시행하였다. 자궁 은 정상 크기였으며 수개의 점막하근종이 있었다. 우측 난관은 전반적 으로 매끈한 편이었으나 부분적으로 지저분하고 불규칙한 부위가 보였 고, 길이 $8.5 \mathrm{~cm}$, 직경 $3.5 \mathrm{~cm}$ 로 부종과 함께 팽대되어 우측 난소와 자 궁체부에 유착되어 있으며, 촉진상 팽대부(ampullar portion)에 소시지 처럼 충실성 종괴로 만져지는 부분이 있었다. 우측 난소는 전반적으로 별 이상 소견이 없었고 우측 난관과 유착되어 있었다. 좌측 난관은 부 종과 함께 팽대되어 있었고 몇 개의 방으로 나뉘어진 낭종이 있었지만 특별히 만져지는 부분은 없었다. 좌측 난소는 육안상 정상이었으며 좌 측 난관과 유착되어 있었다. 그 외 복부 및 골반장기에는 특이 소견이 없었으며 더글라스와에 $50 \mathrm{~mL}$ 가량의 체액이 고여 있었다. 수술 중 양 측 난소와 난관을 동결절편 조직검사를 시행하여 검사상 우측 난관암 으로 진단되어 복강액세포검사, 복식 전자궁절제술 및 양측 난소난관 절제술, 양측 골반 선택적 림프절절제술 및 대망절제술, 충수돌기절제 술을 시행하였다.

병리조직학적 소견: 1) 육안 소견: 자궁은 $8.0 \times 5.0 \times 3.5 \mathrm{~cm}$ 으로 자 궁내 근종 및 점막하 근종이 있었고 무게는 $53 \mathrm{gm}$ 이었다. 우측 난관 은 $8.5 \mathrm{~cm}$ 으로 절단면상 난관의 체부내강에서 발생한 회백색의 고형 성 종괴의 크기는 $1.8 \times 1.8 \times 1.8 \mathrm{~cm}$ 으로 내강으로 튀어나온 양상으로 부분적으로 난관근층내로 침윤하고 있었다. 양측 난소는 정상이었으며 좌측 난관은 난관수종의 모습이 보였다(Fig. 4). 

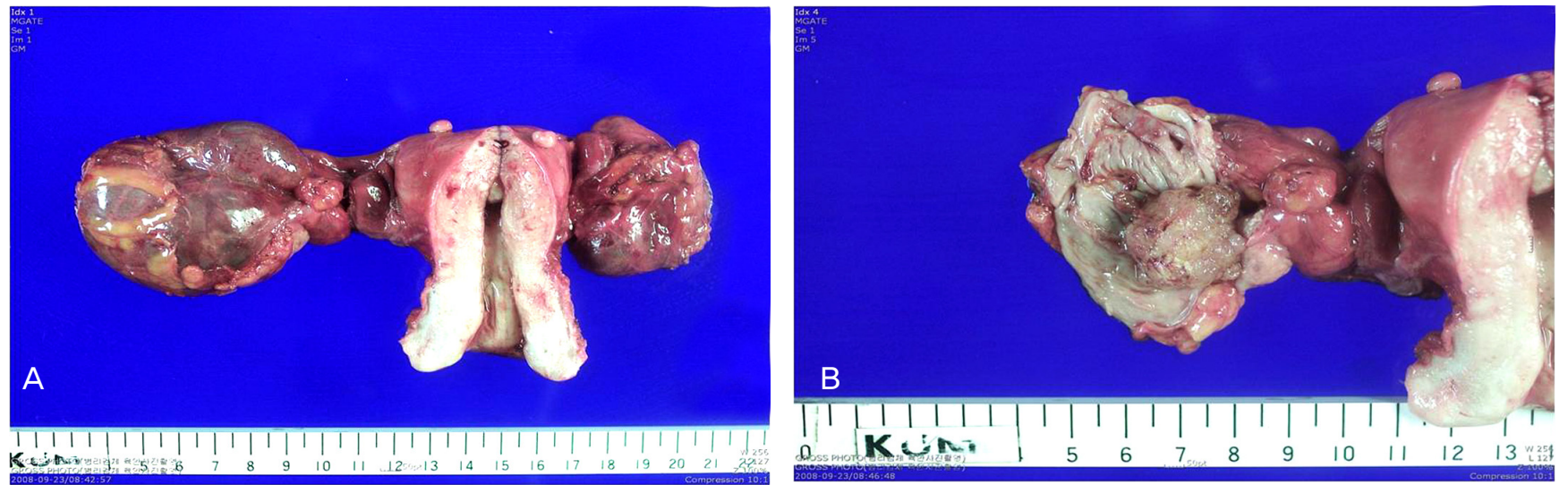

Fig. 4. (A) The right fallopian tube is dilated due to hydrosalpinx the right ovary is grossly unremarkable. (B) Right fallopian tube reveal whitish fiable solid mass $(1.8 \times 1.8 \times 1.8 \mathrm{~cm})$ in lumen.
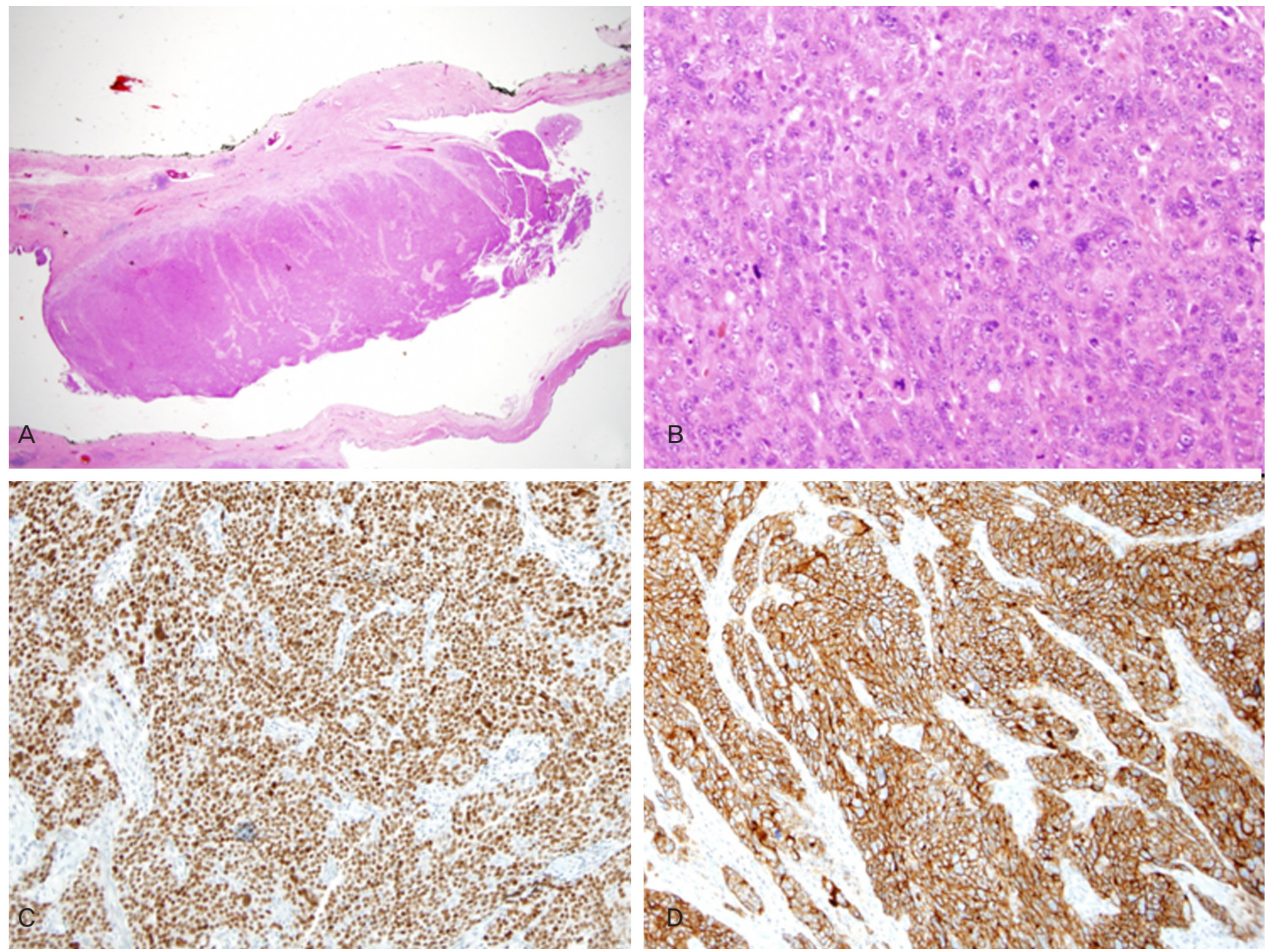

Fig. 5. (A) The lower power view of microscopic finding of solid tumor shows intraluminal growth of fallopian tube with partially infiltrate into the myometrium $(H \& E, \times 40)$. (B) The high power view of solid tumor reveals no papillary or glandular configuration with prominent nuclear pleomorphism and increased atypical mitoses $(H \& E, \times 200)$. (C) The immunohistochemical stain of WT-1 reveals strong nuclear expression $(\times 100)$. (D) The immunohistochemical stain of cancer antigen 125 demonstrates diffusely strong positivity of membranous pattern $(\times 100)$. 
2) 현미경적 소견: 우측 난관 종괴의 현미경 소견은 저배율 소견에 서 인접한 난관내강 상피에서 암종이 발생하여 근육층을 일부 침범하 고 있음을 알 수 있었고(Fig. 5A), 고배율 소견에서 미분화 상피세포의 핵은 심한 이형성 및 과염색성을 보이며, 종양세포내 빈번한 비정형 유 사분열을 관찰할 수 있었다(Fig. 5B). 광학현미경 검색에서 유두상 구 조 또는 선 구조 등을 확인할 수 없어서 장액성 암종의 확인을 위해 면 역조직화학 염색을 시행하였다. 그 결과 WT-1에 대한 면역조직화학염 색에서 강한 핵 양성을 보였고(Fig. 5C), CA 125에 대한 면역조직화학 염색에서 미만성으로 세포막을 따라 강양성을 보였다(Fig. 5D). 복강액 세포검사뿐 아니라 난관 이외에 다른 장기에는 병리학적으로 특이 소 견은 없었다. 이를 토대로, 본 증례의 경우 난관에서 발생한 분화가 나 쁜 장액성 암종으로 진단할 수 있었다.

수술 후 경과: 수술 후 활력징후 및 상처부의 특별한 소견이나 합병증 없이 회복되어서 7일째 퇴원하였다. 이후 항암화학요법을 권유하였으 나 환자의 거부로 시행하지 못하였다. 현재 재발의 증후 없이 외래에서 추적검사 중이다.

\section{고 찰}

난관에서 발견되는 악성 종양은 대부분 난소암이나 자궁내막암 의 전이에 의한 것이며, 원발성 난관암은 모든 부인과 악성 종양의 $0.3 \%-1.0 \%$ 의 빈도로 보고되는 대단히 드문 질환이다[1]. 1988년에 Orthmann에 의해 처음 보고되었으며 발병빈도는 연평균 백만 명 중 3.6명꼴로 통계되고 있다[1]. 발생연령은 20-80세까지 보고되고 있으 나 대개 50-60세의 폐경기 여성에 호발하는 것으로 알려져 있다[2].

원발성 난관암은 개복수술 이전에 진단되는 경우는 매우 드물며, 이 는 드문 빈도와 비특이적인 증상 때문인 것으로 보인다. 흔히 호소하는 난관암의 임상증상 및 증후 중 가장 흔한 것은 비정상 질출혈과 질분비 물이며 이 외에도 골반종괴, 동통 등이 있으며 환자의 $5 \%-20 \%$ 에서 관 찰된다[2]. 그러나 이러한 증상은 비특이적인 증상으로 진단에 도움을 준다고 보기는 힘들다. 이것은 원발성 난관암 232예의 후향적 조사에 서 총 6 예만이 수술 전 진단이 가능했음을 보여주는 Sedlis [3]의 보고 에서도 알 수가 있다. 난관암이 수술 전에 진단된 경우는 3\%-5\%로 진 단이 매우 어려운 부인과 종양 중의 하나로 여겨지기에 증례를 보고하 는 바이다. 현재 난관암이 의심되는 경우에 시행되는 검사에는 각종 세 포검사와 CA 125 와 같은 종양 표지물질의 측정, 초음파검사를 포함한 여러 영상 기법 등이 있다[3].

Takashina 등은 난관암이 의심되는 환자에 수술 전 시행하는 각종 세포학적 검사에서 $45.9 \%$ 의 양성률을 보고하면서 주의 깊은 검체 채 취를 통해 진단적 효용성을 높일 수 있다고 하였다. 그러나 대부분의 연구에서는 10\%-20\% 정도의 낮은 양성률을 보고하였다[4]. CA 125 는 상피성 난소 종양을 비롯하여 체강상피에서 기원하는 종양에 의해 생성되는 항원으로 난관 선암을 가진 환자의 치료와 추후 관찰기간에 조기 종양의 파급에 대한 매우 민감한 지표가 된다는 보고가 있다[5].
Kurjak 등[6]은 수술 전 영상검사에서 유두양 증식(papillary projection) 을 동반한 소시지 모양의 고형 또는 낭성 자궁부속기 종괴가 관찰되면 서 도플러초음파검사상 낮은 혈관 저항(low impedence Doppler flow) 소견을 들었고, Kawakami 등[7]은 원발성 난관암 환자 10 명의 수술 전 전산화단층촬영과 자기공명영상촬영을 분석한 결과 원발성 난관암 과 관련된 유일한 소견으로 난관수종을 보고하였다. Kahng 등[8]은 수 술 후 확진된 원발성 난관암 환자 7 명의 임상 소견과 수술 전 전산화 단층촬영 및 자기공명영상 촬영을 분석한 결과 난관수종이나 자궁강내 액체저류를 동반한 자궁부속기의 고형 또는 복합성 종괴가 보이는 경 우가 진단에 도움이 된다고 기술하였다. 특히 난관수종과 자궁강내 액 체저류는 종양의 병태 생리와 밀접한 관계가 있다고 보고하였는데, 이 는 난관의 원발성 악성 종양은 많은 양의 체액을 분비하는 경향을 지 니고 있어 종양에 의해 난관폐색이 있는 경우 분비된 체액의 축적으 로 인해 난관수종이 생기고, 난관폐색이 없는 경우는 자궁강내로 체액 이 유입되어 자궁강내 액체 저류를 초래하거나 복강내로 배출되어 복 수를 유발하는 것으로 알려져 있다[9]. 특히 난관수종이 있는 경우에 는 영상 소견상 소시지 모양의 낭성 종괴 내부에 난관벽에서 자란 종괴 가 쉽게 확인되며 난관수종의 정도가 심할수록 이러한 소견은 더욱 두 드러져 난관의 원발성 악성 종양의 진단에 도움이 된다[6]. 난관의 폐 색 여부는 영상뿐만 아니라 임상적으로도 다른 양상을 보이는 원인이 되는데 난관의 폐색으로 인한 난관수종은 하복부 또는 골반강에서 촉 지되는 종괴로 나타날 수 있다. 대조적으로 난관폐색이 없는 경우는 자 궁강내로 유입된 체액에 의한 과도한 질분비물이 주 증상으로 나타난 다. 또한 간혹 폐색된 난관이 일시적으로 개통된 경우에는 촉지되던 종 괴와 하복부 통증이 소실되면서 과도한 질 분비가 나타나서 Roberts와 Lifshitz [10]은 이를 hydrops tubae profluens로 명하고 난관종양의 특 징적인 임상소견으로 기술하기도 하였다. 본 예에서는 CA 125수치는 낮았지만, 환자가 질출혈을 동반하였고, 초음파 소견상 소세지 모양의 우측 자궁부속기와 낭성 종괴 내부에 난관벽에서 자란 종괴가 보였고 전산단층화촬영상 우측 자궁부속기에 소세지 모양의 낭성 종괴가 관찰 된 것이 난관암 진단에 도움이 되었다고 여겨진다. 난관암은 속발성이 대부분이며 원발성은 매우 드물어 $\mathrm{Hu}$ 등[11]은 원발성 난관암의 진단 을 위한 조건으로, 첫째, 육안적으로 난관내에 주종양이 있고 난관내막 에서 발생해야 하고, 둘째, 조직학적으로 점막상피를 보이고 유두상 구 조를 나타내며, 셋째, 난관벽에 종양이 있으면 난관의 양성 상피와 악 성 상피 사이에 이행 부위가 존재하여야 하며, 넷째, 난소과 자궁내막 이 정상이거나 종양이 있으면 난관의 종양보다 크기가 작아야 된다고 정의하였다. 조직학적 분류상 대부분은 장액성 선암이나 드물게 육종, 혼합성 중배엽성 종양, 림프종, 암육종, 선편평세포암종 등이 보고되어 있다[12]. 본 예는 가장 흔한 장액선선암으로 진단되었다. 호발 부위는 난관 팽대부와 난관 체부이며 대개 편측성인 경우가 많으나 5\%-26\% 에서는 양측으로 존재한다고 한다[10]. 본 증례에서는 난관 체부와 팽 대부에서 발생된 암종이었고 편측성이었으며 조직학적 소견상 분화도 가 낮은 장액성 선암종으로 난관암 중 가장 흔한 세포형이었다.

원발성 난관암의 전이는 상피성 난소암과 유사한 방법으로 이루어지 
는데 원발성 난관암에서 림프절과 원격 전이가 더 흔한 것으로 보고되 며 이는 난관이 자궁과 난소에 연결되는 림프절 연결이 풍부하여 골반 및 동맥주위 림프절로 배액되기 때문으로 알려져 있다[13]. 또한 난관 암이 지속되는 경우와 재발은 림프절에서 가장 흔하게 발견된다는 보 고가 있으므로 난관암의 병기설정 수술 시 낮은 병기에서도 림프절절 제를 해야 하는 근거가 된다[10]. 본 예에서도 병기 설정 수술은 림프 절절제까지 모두 시행하였다. 원발성 난관암의 치료에는 외과적 수술 요법과 수술 후 항암화학요법 등의 상피성 난소암의 치료원칙이 적용 된다. Benedet 등[14]은 난소암 분류방법과 유사한 수술적 병기체계를 제시하였다. 즉, 수술은 복강액 세포검사, 양측 부속기절제술, 전자궁절 제술, 대망절제술, 복막 생검, 골반과 동맥주위 림프절절제술 등을 포함 한 병기설정술을 시행하고 전이가 있는 경우 가능한 최대한의 종양제 거를 시행해야 한다. 수술적 절제에도 불구하고 상대적으로 높은 재발 의 위험 때문에 보조적 항암화학요법(adjuvant chemotherapy)을 시도 하는데 cisplatin을 포함한 항암화학요법이 가장 흔히 사용되는 것으로 알려져 있고 말기 환자 53\%-92\%에서 객관적인 반응을 보인다고 하였 다[2]. 부인과 양성 질환의 수술 중 예상하지 못했던 난관암이 발견되 는 빈도는 전체 원발성 난관암의 $6 \%-11 \%$ 로, 수술 시 자궁부속기의 철 저한 확인이 이루어져야 하며 우연히 발견된 난관암의 향후 치료에 있 어 병기 설정을 위한 시험개복술이 반드시 필요하며, 이후 병기에 따른 적절한 추가적 항암화학치료를 시행해야 한다[15]. 본 예에서는 수술 전 난관암이 의심되어 이에 준하여 수술적 치료에 임하였으며 림프절 및 타 장기에 전이 소견이 보이지 않아 병기 IA로 확인되었으나 세포의 분화도가 좋지 않아 보조적 항암화학요법을 시행하고자 하였으나 환자 의 거부로 시행되지 못하였다. 저자들은 질출혈과 부속기종괴를 주소 로 외래 방문한 폐경기 여성에서 영상학적 검사를 통해 수술 전 진단된 원발성 난관암 1 예를 경험하였기에 문헌고찰과 함께 보고하는 바이다.

\section{References}

1. Rosenblatt KA, Weiss NS, Schwartz SM. Incidence of malignant fallopian tube tumors. Gynecol Oncol 1989;35:236-9.

2. Dodson MG, Ford JH Jr, Averette HE. Clinical aspects of fallopian tube carcinoma. Obstet Gynecol 1970;36:935-9.

3. Sedlis A. Primary carcinoma of the fallopian tube. Obstet Gynecol Surv 1961;16:209-26.
4. Johnston GA Jr. Primary malignancy of the fallopian tube: a clinical review of 13 cases. J Surg Oncol 1983;24:304-9.

5. Lootsma-Miklosova E, Aalders JG, Willemse PH, de Bruijn HW. Levels of CA 125 in patients with recurrent carcinoma of the fallopian tube: two case histories. Eur J Obstet Gynecol Reprod Biol 1987;24:231-5.

6. Kurjak A, Kupesic S, Ilijas M, Sparac V, Kosuta D. Preoperative diagnosis of primary fallopian tube carcinoma. Gynecol Oncol 1998:68:29-34.

7. Kawakami S, Togashi K, Kimura I, Nakano Y, Koshiyama M, Takakura K, et al. Primary malignant tumor of the fallopian tube: appearance at CT and MR imaging. Radiology 1993;186:503-8.

8. Kahng YR, Kim JK, Cho KS. Primary malignant tumor of the fallopian tube: CT and MR features. J Korean Radiol Soc 2001;45:393-7.

9. Subramanyam BR, Raghavendra BN, Whalen CA, Yee J. Ultrasonic features of fallopian tube carcinoma. J Ultrasound Med 1984;3:391-3.

10. Roberts JA, Lifshitz S. Primary adenocarcinoma of the fallopian tube. Gynecol Oncol 1982;13:301-8.

11. Hu CY, Taymor ML, Hertig AT. Primary carcinoma of the fallopian tube. Am J Obstet Gynecol 1950;59:58-67.

12. Kim TS, Jang HS, Han DG, Kim SL, Choi YC. A case of primary adenosquamous carcinoma of the fallopian tube. Korean J Obstet Gynecol 1994;37:1865-71.

13. Oh YS, Yi SW, Huh CY, Kim SB. Two cases of primary carcinoma of the fallopian tube. Korean J Obstet Gynecol 1999;42:184953.

14. Benedet JL, Bender H, Jones H 3rd, Ngan HY, Pecorelli S. FIGO staging classifications and clinical practice guidelines in the management of gynecologic cancers. FIGO Committee on Gynecologic Oncology. Int J Gynaecol Obstet 2000;70:209-62.

15. Jung YJ, Chi KS, Kim JS, Kim KW, Kim DG, Yang HS, et al. 3 cases of primary tubal cancer incidentally diagnosed after benign gynecologic operation. Korean J Obstet Gynecol 2006;49:1779-87. 


\section{수술 전 영상학적으로 진단된 원발성 난관암 1예}

계명대학교 의과대학 ${ }^{1}$ 산부인과학교실, ${ }^{2}$ 병리학교실

최준국 ${ }^{1}$ 최준용 ${ }^{1}$, 김선연 ${ }^{1}$, 권선영 $^{2}$, 신소진 ${ }^{1}$, 조치흠 ${ }^{1}$, 차순도 ${ }^{1}$, 권상훈 ${ }^{1}$

원발성 난관암은 발생빈도가 매우 낮은 부인암으로 전형적인 증상이 없어 수술 전 진단이 매우 어려운 질환이다. 그 원인으로 비특이적 인 양상을 나타내며 질병자체의 빈도가 낮으며 여러 진단적 기법이 난관암을 인지하는 데 있어 민감하지 못하기 때문이라고 생각된다. 본 저자들은 본원에서 영상학적 검사를 통해 수술 전 진단된 원발성 난관암 1 예를 경험하였기에 간단한 문헌고찰과 함께 보고하는 바이다.

중심단어: 원발성 난관암, 수술 전 진단 